\title{
SOFIA GUBAIDULINA'S RELATIONSHIP WITH GOD - COMPOSITIONAL, TECHNICAL AND INTERPRETATIONAL FEATURES OF HER MUSIC
}

\author{
UDC 78.08”20“ Sofia Gubaidulina
}

\author{
Nikola Peković \\ University of Niš, Faculty of Arts, Niš, Serbia
}

\begin{abstract}
The paper presents the compositions De Profundis for solo accordion, Et Exspecto for solo accordion and In Croce for accordion and cello, by one of the today's highly appreciated composers, Sofia Gubaidulina. De Profundis is the first work by Gubaidulina for solo accordion, composed in 1978. In this work, Gubaidulina changed the ordinary sound of the accordion that she encountered in the Russian folk music, so that the sound of the accordion acquired a brand new dimension. Et Exspecto is the composition written in 1985 and has five movements. The composer expresses herself through different techniques and effects: air release valve, fast passages, tremolos, moving and static clusters, clusters by a trembling hand with a vibrato effect, etc. In Croce is a composition written in 1979 for cello and organ dedicated to the cellist Vladimir Tonkha. Gubaidulina, together with the accordion professor and artist Elsbeth Moser, rearranged In Croce for cello and accordion in 1991. The composition rests on specific crisscrossing of melodic lines, and it creates a visual impression of a cross with the listeners.
\end{abstract}

Key words: contemporary music, Sofia Gubaidulina, De Profundis, Et Exspecto, In Croce

Sofia Gubaidulina (1931) is considered to be one of the leading Russian contemporary composers together with Alfred Schnittke (1934-1998) and Edison Vasilievich Denisov (1929-1996). She started composing at the age of six. Until 1959 she studied composition at the Moscow Conservatory with Nikolay Ivanovich Peyko (1916-1995), Shostakovich`s assistant, and then did postgraduate work with Vissarion Shebalin. She mastered her performance skills as a percussionist (Sitsky 2002, 56). In her youth, Gubaidulina was also an excellent concert pianist.

Received: October 2017 / Accepted November 2017

Corresponding author: Nikola Peković

University of Niš, Faculty of Arts, Niš, Serbia

E-mail: pekovic.nikola@yahoo.com 
She was born in the Tatar Autonomous Republic, U.S.S.R. (now Russia) as daughter of a land-surveying engineer and a teacher. Her grandfather was a mullah, yet she is a devout and outspoken Christian (Ross 1997, 110). Gubaidulina gained world recognition in the 1980s everywhere but in the Soviet Union where her music was kept away from the public because she was an avant-garde composer. Other factors that doomed Gubaidulina`s works to non-performance and non-publication were her predilection for mysticism and metaphysics, her outspoken religious spirituality, her preoccupation with musical images of the apocalypse and the last judgment, and her interest in developing religious musical symbols, such as of the cross, crucifixion, resurrection, and transfiguration (Lukomsky \& Gubaidulina 1998b, 29). It was only Shostakovich who encouraged her with one of his typical gnomic utterances: "Everybody thinks that you are moving in the wrong direction, but I wish you to continue on your 'mistaken' path" (Lukomsky \& Gubaidulina 1998a, 16). Compared to Schnittke and Denisov, Gubaidulina seems to have remained relatively unaffected by Shostakovich's imposing influence. She said: "Nobody took much notice of me. They could always dismiss what I did as simply female eccentricity" (McBurney 1988, 121). The opus of Sofia Gubaidulina includes symphonic and choral music, two concerts for cello, a concert for viola, four string quartets, a string trio, compositions for percussion ensembles, and many other non-standard instruments and instrumental combinations, including the accordion. Her works are often based on discovering unconventional techniques of making sound. Her work with an ensemble of traditional instruments, that the composers associated with it addressed as non-traditional classical music in the 1970s, aroused her interest for the bayan ${ }^{1}$, which eventually triggered her concern for the accordion. She is considered to be the composer with the most significant contribution to the development of accordion literature, and has inspired both performers and composers to pay more attention to this instrument. Gubaidulina has shown more interest in composing for the classical accordion more than any other living $20^{\text {th }}$ century composer. This interest may have grown in the 1970s from her involvement with a group of composers interested in assembling ancient and traditional instruments and writing highly modern classical music for them. She composed the following pieces for accordion:

\section{Solo accordion}

De Profundis - dedicated to Friedrich Lips (1978)

Et Exspecto - dedicated to Friedrich Lips (1985)

Kadenza - edited by Iñaki Alberdi (2011), from Under the Sign of Scorpio orchestral work (2003)

\section{Chamber music}

In Croce for cello and organ - dedicated to Vladimir Tonkha (1979), for accordion and cello edited by Elsbeth Moser (1991)

Silenzio - five pieces for accordion, violin, and cello - dedicated to Elsbeth Moser (1991), for bayan, violin, and double bass (2010)

\footnotetext{
${ }^{1}$ The bayan is a type of chromatic button accordion developed in Russia in the early $20^{\text {th }}$ century. http://www.barynya.com/russianmusic/Bayan-russian-accordion.htm (accessed on_28. 05. 2017).
} 
Gallow Songs à 5 - fourteen pieces for mezzo-soprano, flute, percussion, bayan and double bass on poems by Christian Morgenstern - dedicated to Ensemble "That" (1996)

Tatar Dance for bayan and two double basses - dedicated to Viktor Suslin (1992)

\section{For orchestras}

Seven Words [of Jesus Christ on the Cross] for violoncello, bayan and strings dedicated to Friedrich Lips and Vladimir Tonkha (1982)

Under the Sign of Scorpio - variations on six hexachords for bayan and large orchestra, dedicated to Friedrich Lips (2003)

Fachwerk for accordion, percussion and strings, dedicated to Geir Draugsvoll (2009)

Triple Concerto for violin, violoncello, accordion and symphony orchestra, dedicated to Elsbeth Moser (2016)

Gubaidulina is a member of the Berlin Academy of Arts, Hamburg Academy of Arts, Royal Music Academy of Stockholm and the winner of "Pour le Mérite" in Germany. She has received many awards for her artistic work all around the world. Her music was published for the following music publishers: "DG", "Chandos", "Philips", "Sony Classical", "BIS", "Berlin Classic Labels" etc.

\section{DE PROFUNDIS}

Gubaidulina began working together with the bayan artist Friedrich Lips in the second half of the 1970s. At the time, Lips has fundamentally reformed the technique of classical accordion playing. Lips showed to Gubaidulina all the abilities of the accordion and he was surprised how accurately she approached it in inquiring about the details. As a result of this collaboration, she composed the one-part composition for accordion De Profundis. It was completed in 1978 when Gubaidulina took the notes and brought them to "Gnesin Institute" so that she could play them to Professor Lips. Lips commented: "I was enchanted not only with the music, but also how well she used the reeds of the bayan which showed the acoustic potential of the instrument in a fresh new way. At my request she introduced for the first time into Russian musical literature the tonal glissando (for accordion). Of course, I had to make some editorial corrections, when working on this piece, to make the notation more comfortable for bayan players, still this was not work, but a pleasure" (Kurtz 2007, 134). The composition was dedicated to Lips and he premiered it on April $8^{\text {th }} 1980$ in Moscow Youth Musical Club, at the concert called "Meet the Composer". Today, De Profundis is known to be one of the most recognizable compositions in the accordion literature and undoubtedly one of the best.

Similar to all her works, this one has religious meaning which is presented by the very title and by the effects she used in the composition. De Profundis is the opening of the Latin translation of the $130^{\text {th }}$ Psalm, rendered in English as "Out of the depths I cry to thee, O Lord", a song of ascents. 


\section{Psalm 130}

Lord, hear my voice.

Let your ears be attentive

to my cry for mercy.

If you, Lord, kept a record of sins,

Lord, who could stand?

But with you there is forgiveness,

so that we can, with reverence, serve you.
I wait for the Lord, my whole being waits, and in his word I put my hope.

I wait for the Lord

more than watchmen wait for the morning, more than watchmen wait for the morning.

Israel, put your hope in the Lord, for with the Lord is unfailing love and with him is full redemption. He himself will redeem Israel from all their sins. ${ }^{2}$

The composition opens with a sept-chord in the instrument's lowest register and the performer can recognize the lowest frequencies of the accordion that evoke depth. In the following course of the composition the sept-chord becomes the basis for the chromaticism which, combined with bellows shake, and in accordance with the title of the composition (De Profundis), portraits man's eternal spiritual fight between light and darkness.

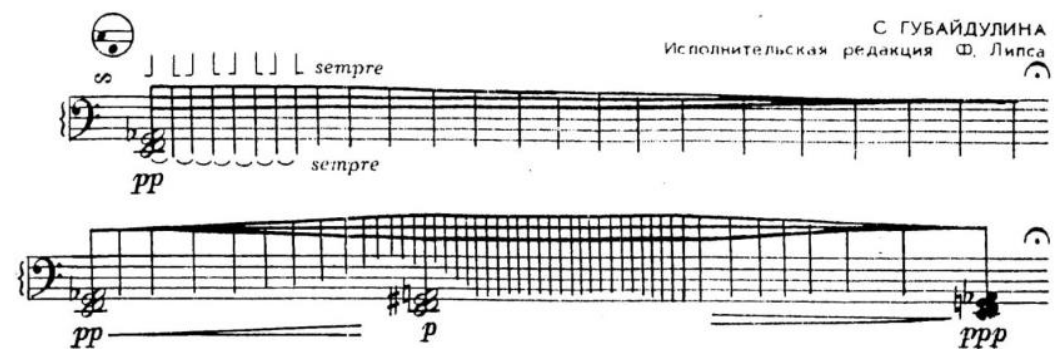

Example no. 1 The beginning of De Profundis brings lowest frequencies of the accordion which emphasize the depth

The search for light which emerges from time to time is evoked by the clusters in the upper register. Man's striving to escape darkness gets more intense due to accelerated bellows shake combined with the increasing wavy dynamics (pianissimo possibile fortissimo) in the ascending and descending clusters. The opening part of the composition is typical for alternating pattern of rises and falls, followed by a part of the composition in which the artist exposes hope in the form of a coral structure in the left hand and starts subito piano. In the left hand part there is a melody in chords contrasted to the thrillers and passages in the right hand.

\footnotetext{
${ }^{2}$ https://www.biblegateway.com/passage/?search=Psalm+130 (accessed on 29. 05. 2017).
} 


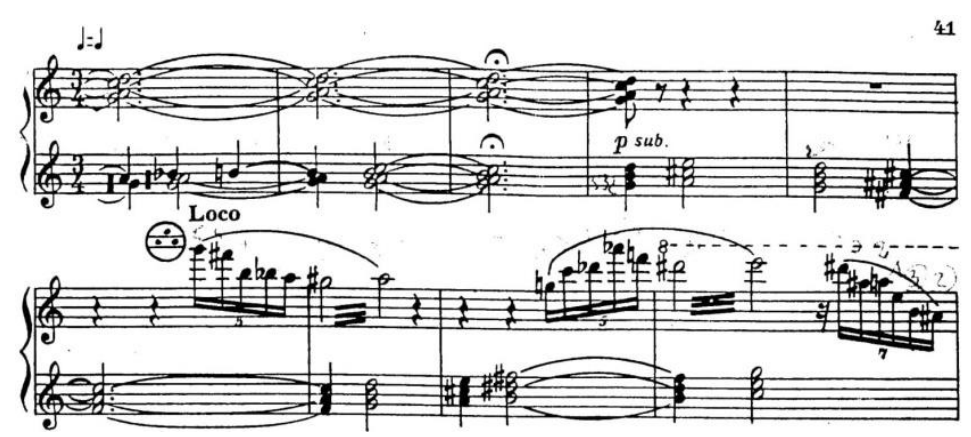

Example no. 2 Part of De Profundis in which the artist reveals the hope in the form of a coral structure in the left hand

Such compositional-technical means evoke two pronouncedly different moods that are very demanding for the performer. The whole composition is abundant in rises and falls, a fight between good and evil. Further on in the composition there are numerous effects like shuddering vibratos, clusters, glissandi, and quasi percussive effects that evoke light and darkness in the best way. The composer ingeniously designed the culminating part followed by the "sighs" of the accordion achieved by pressing the air release valve.
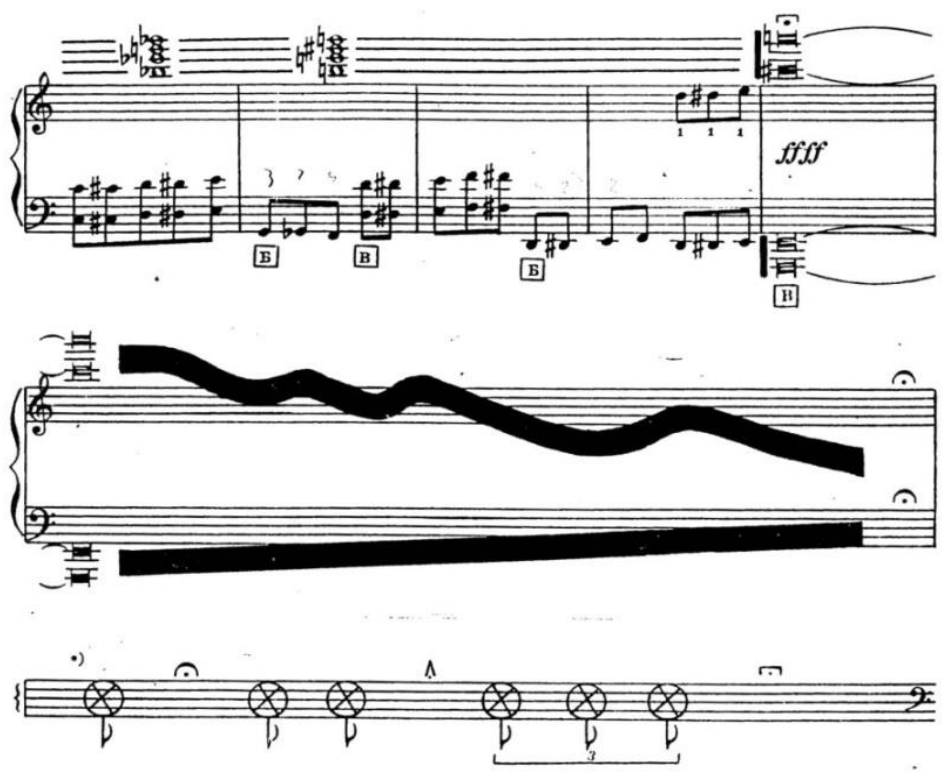

Example no. 3 The culminating part in De Profundis followed by the "sighs" achieved by pressing the air release valve 
This is followed by long single-line melody suggesting prayer. At the end of the piece, there is a slow coral in the right hand which attempts to rise from troubled darkness to bright light, after which the composition ends with reminiscing on the motive from the beginning.

\section{ET EXSPECTO}

Gubaidulina was particularly delighted by the accordion's ability to "breathe" which was presented in the solo sonata for bayan - Et Exspecto. This composition is also a fruit of collaboration between Lips and Gubaidulina. It was written in 1985 and consists of five movements. The title Et Exspecto [resurrectionem mortuorum] implies the Latin version of the statement from the Christian Credo, "And I expect the Resurrection of the dead". This work is also known as one of the most famous and often played pieces for the accordion nowadays. Gubaidulina used numbers from the Fibonacci series as an essential constructive principle for this piece. ${ }^{3}$

The accordion artist, Mie Miki from Japan, once said in a discussion at a concert in Germany: "This piece spoke to me because I sensed three elements. First, there was something beautiful, something good, something sacred. Secondly, there came something dark and disturbing. These opposite characteristics are always within us, within society, in our life as a whole, and these two elements are here juxtaposed. For me, it means something like heaven and earth. The third element is breath - the wind that connects heaven and earth. The music begins in a very high, bright register and gently comes down to earth as with the wind, and when it lands on earth, that's the beginning of the drama..." (Kurtz 2007, 134-135). The first movement begins with clusters in pianissimo with dynamics that imitates breathing, after which there comes the air release valve which additionally describes breathing.

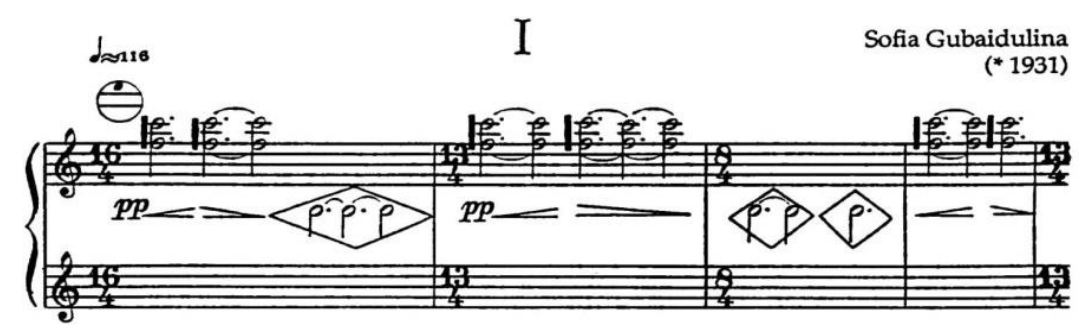

Example no. 4 The beginning of the first movement (Et Exspecto), where the composer imitates breathing with clusters and the air release valve

The entire first movement is filled with various chords, clusters and effects of breathing, presenting the beginning of everything, the outbreak of life and birth. The rhythm and breathing dynamics constantly change during the composition, evoking a feeling that the accordion is a human soul. In the end there are a number of ricochets ${ }^{4}$ (triolet, quartolet,

\footnotetext{
${ }^{3}$ In the Fibonacci series, each subsequent number is the sum of the previous two (e.g. 1, 1, 2, 3, 5, 7)

${ }^{4}$ Ricochet is a bellow-movement, which is similar to bellow-shakes.
} 
quintolet) most commonly followed by a vibrato effect, after which comes a glissando through the changes of register that introduces the second movement.

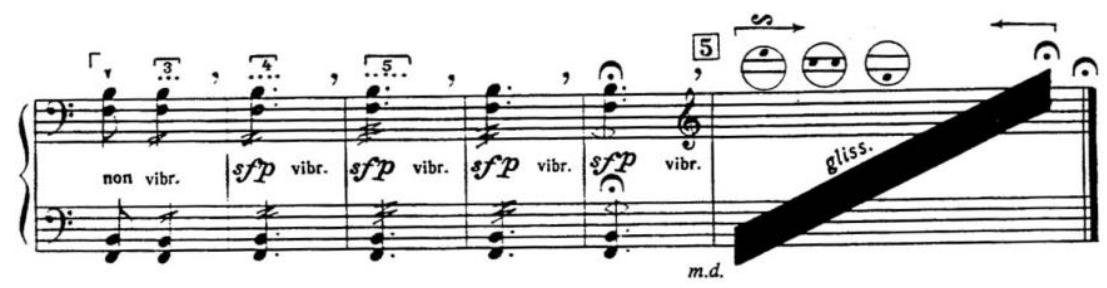

Example no. 5 The end of first movement (Et Exspecto), with a number of ricochets followed by a vibrato effect

The second movement brings forth a prayer. The composer wanted to show us the church and the relationship between the cantor and the chorus through the wavelike dynamic followed by unisonous passages.
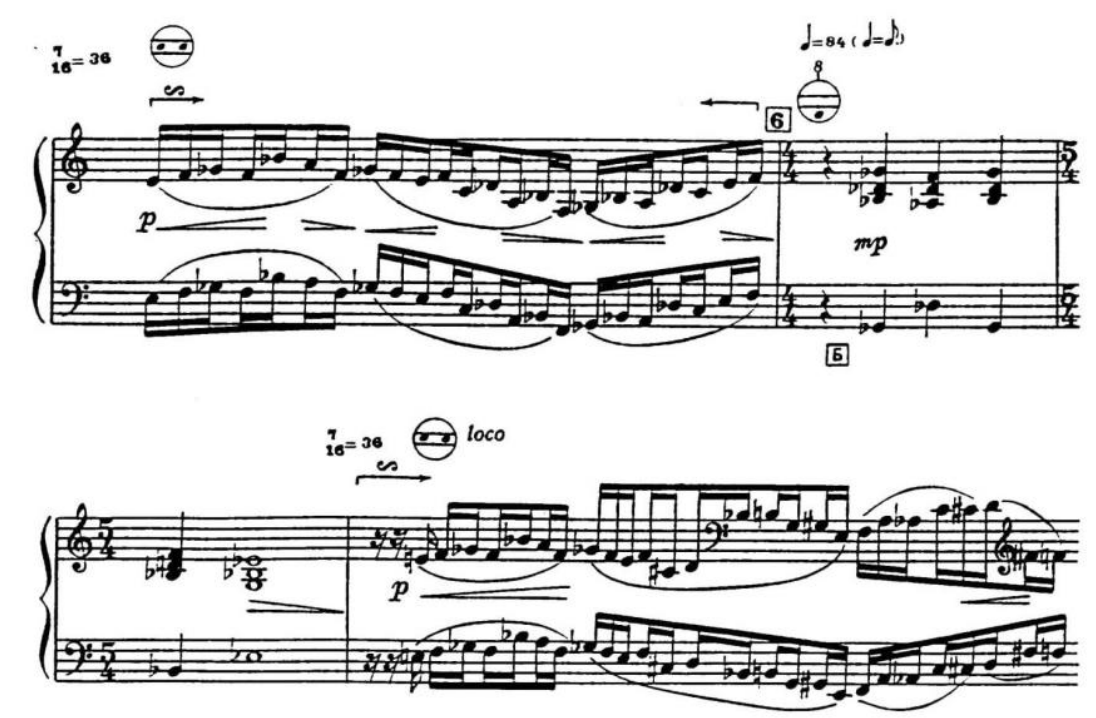

Example no. 6 The beginning of the second movement (Et Exspecto) represents the relationship between the cantor (passages) and the chorus (chords)

The composer places the chorus in the darker register with coral structure. As this movement develops, so do the dynamics and agogics. The following step is that the material from the first part is used with dynamic and rhythmic variations, as well as with a change in sound timber and register.

The third movement brings a new atmosphere which is a consequence of a faster tempo (presto), the use of sixteenth notes and abrupt changes of bellows. This specific choice of musical effects aims at showing the course of life in its full complexity. It begins with a cluster 
played with a tremble of the hand through a vibrato effect that keeps reappearing throughout the composition. This movement is very dramatic and it introduces us to a growingly uncertain "suspension" through seconds, moving and static clusters, up to the culminating point of the movement where all the effects are played in prestissimo and forte fortissimo. The cluster in the left hand sounds like a scream of a dying person.

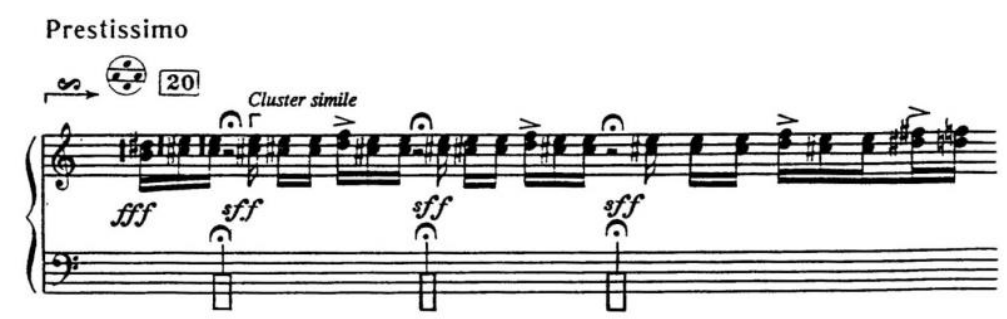

Example no. 7 The culmination of the third movement (Et Exspecto) where the left hand sounds like a scream

The elements of unity at the level of the cycle are achieved using the same thematic material similar to the end of the first, second and third movements. The last two clusterglissandos in the left and right hand in the last measure of the third movement are an introduction to something completely different, a movement abundant in coral structure.

The fourth movement portrays the end of everything, the end of life itself. The chords used by the composer are utterly imposing and unique. As Mie Miki put it, they connect heaven and earth in the best possible way (Kurtz 2007, 135).

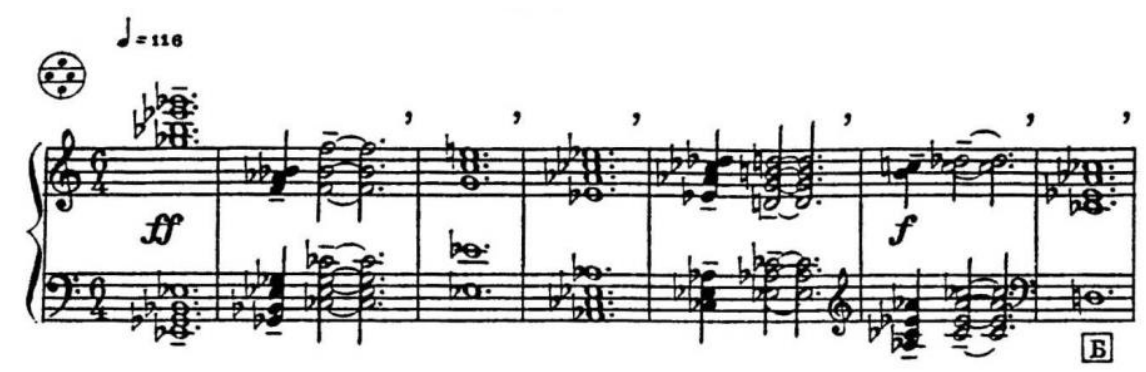

Example no. 8 Beautiful and mysterious chords from the beginning of the fourth movement (Et Exspecto)

At certain moments, they are tonal chords - beautiful and mysterious, while at other moments they are dissonant clusters that later look like a line of chords growing further apart. The form of the fourth movement reminds of Bach's corals. The chords keep developing up to the culminating part, made up of the alternating clusters of the right and the left hand through the wavelike rhythmical expression in fortissimo possibile dynamics. This method can be interpreted as the end of life, after which Gubaidulina uses the air release valve effect in order to show the last breaths and imminent death. 
The fifth movement embodies what comes after death - resurrection. The tones are actually floating through space. The left and the right hand play a completely different material, while the right hand brings forth a passage that lasts until the end of the composition, the left hand is rich with clusters and thrills which can be seen in the very beginning.

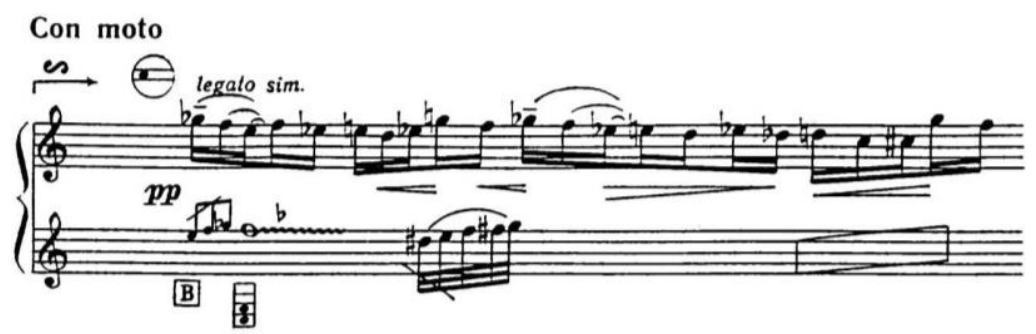

Example no. 9 The beginning of the fifth movement (Et Exspecto), where the right and the left hand are completely different

In the last movement, the melodic line as well as clusters with trills, move towards a lower register, growingly deeper, until they vanish. The last cluster and the sigh of the air release valve remind us of a long awaited resurrection and calming peace of the soul.

\section{IN CROCE}

In Croce was written in 1979 for cello and organ dedicated to the cellist Vladimir Tonkha. It is also called On the Cross or Cross-Wise and brings the Christian motifs, just like the previous two compositions, but under a much clearer title. Vladimir Tonkha asked Gubaidulina to compose a work for a concert he was supposed to perform in Kazan, which was very inspirational for her. She had a lot of free time during that period, so she immediately started composing and she finished the work within only twenty six days. Two days before the concert, she went to Kazan, where Tonkha and a Tatar organist Rubin Abdullin performed the composition in the hall of the Conservatorium on March $27^{\text {th }} 1979$. Abdullin commented during the rehearsals that Gubaidulina only had two words for them to explain the work: "In Croce"! (Ibid., 140). Together with professor and accordion artist Elsbeth Moser, Gubaidulina rearranged In Croce in 1991 for accordion and cello. During the first part of the accordion section there is relatively diatonic music in the upper part of the register, while in the cello section there are tones in the lower register. Both instruments center their movements on the E note.

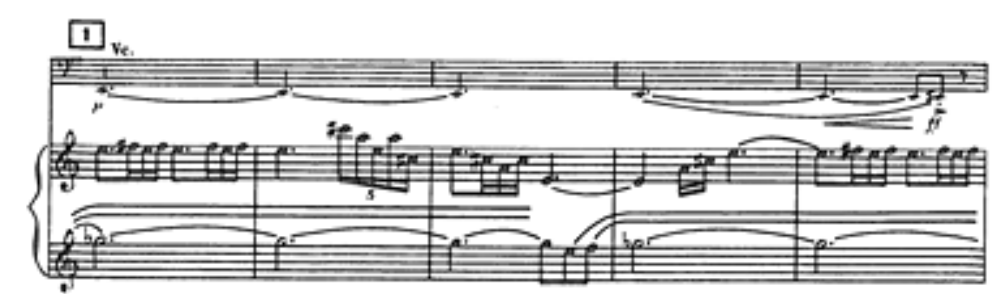

Example no. 10 At the beginning of In Croce both instruments center their movement on the E note in different registers 
As the work progresses, the two instruments start growing closer to each other as the accordion part shows more and more movement and enters the middle register, while the cello moves towards the upper register, resulting in the most aggressive part of the composition, followed by clusters in the accordion and tremolos in the cello part. After a few wild moments on both instruments, there is a brief pause followed by a part where the crossbars meet to form a cross as the climax of the whole composition.

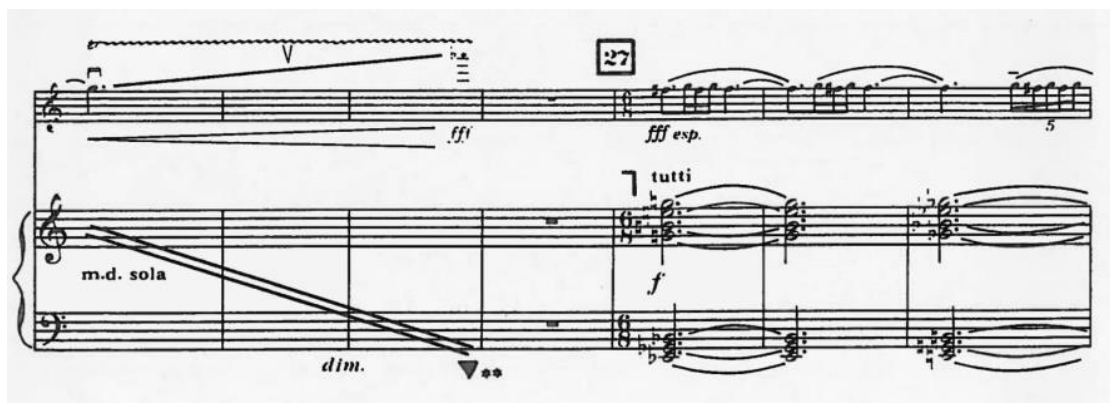

Example no. 11 The middle part of In Croce where the crossbars meet to form a cross as the climax of the composition

After this section, the sound decreases and sounds somehow muffled. The composer uses numerous effects on both instruments so as to show the sacrifice of Jesus Christ and the suffering he endured while crucified. After all those effects and a cadenza played by the cello, the accordion begins a melody line in the upper register, using similar material from the very opening, while the cello starts from the lower register. In the course of that particular part, the melody lines crisscross again, which gives them even more relevance because of the left hand on the accordion that brings forth dissonant chords, creating a convincing impression of the cross. During that time, the cello part perpetuates the denuded texture of the melody line that keeps rising. At this point, composition gradually develops dynamically and reaches to ffff dynamics where the ends of the cross are, and the melodic lines have been completely separated. This moment is suggestive of the moment when Jesus dies on the cross. Differently from the beginning, the accordion ends up in the low register while the cello finishes in the high register creating the impression of peace, suggestive of the moment when Jesus finally leaves the earthly world.

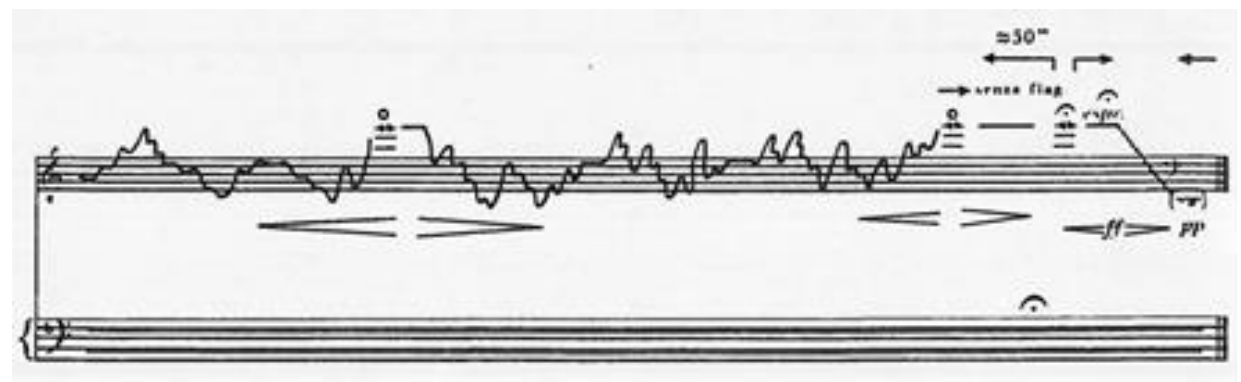

Example no. 12 End of In Croce presenting the moment when Jesus finally leaves the earthly world 


\section{INSTEAD OF A CONCLUSION}

Sofia Gubaidulina wrote Et Exspecto, De Profundis and In Croce while living in the USSR. At that time religion was banned there, a fact that gives even more importance to the above mentioned compositions and shows both, her great faith to God and her willingness to fight the regime. Aside from the composer's relationship with God, the analyzed works are illustrative of the contemporary music language. Frequent use of clusters of all kinds, tempered and untempered glissandos, bellows-shake, dissonant chords, air release valve, ricochets, polyrhythms and fractured melody lines, cumulatively and undeniably indicate a wide palette of compositional-technical mediums used to evoke certain biblical scenes. I have noticed that Gubaidulina begins all three compositions in the piano dynamics, slowly builds up the theme material, brings it to a climax and then brings back the piano dynamics from the beginning. This method of composing is also noticeable in the Silenzio piece. Gubaidulina leaves us with the impression that she loves to start her compositions from nothing, only to return to nothing again. All in accordance with her own words: "Composers should think about depth, not innovations" (Lukomsky and Gubaidulina 1998a, 8). On one occasion she said that her going deeper and deeper into the labyrinth of her soul embodies her search for something new. And ever so successful she is.

Performing pieces by Sofia Gubaidulina and getting to know them well brought me to the point of understanding life in an entirely different way. In her pieces the frequencies that the accordion makes truly affects the comprehension of the surrounding where the question of life and death is always asked. Through her compositions she unquestionably carries out her mission of Christianity mirroring her dedication to prayers and to God.

\section{REFERENCES}

Beyer, A. and J. Christensen (2001). Sofia Gubaidulina: Into the Labyrinth of the Soul, In: A. Beyer (Ed), The Voice of Music, conversations with composers of our time. London: Ashgate, 43-52.

Kurtz, M. (2007). Sofia Gubaidulina: A biography. Bloomingron: Indiana University press.

Lukomsky, V. \& S. Gubaidulina (1998a). My Desire Is Always to Rebel, to Swim against the Stream, Perspectives of New Music, Vol. 36, No. 1: 5-41.

Lukomsky, V. \& S. Gubaidulina (1998b). The Eucharist in My Fantasy: Interview with Sofia Gubaidulina, Tempo, No. 206: 29-35.

McBurney, G. (1998). Encountering Gubaydulina, The Musical Times, Vol. 129, No. 1741: 120-125.

Sitsky, L. (2002). Music of the twentieth-century avant-garde: a biocritical sourcebook. Westport, Conn: Greenwood Press.

Ross, A. (1997). Musical Events - Russian soul. The exotic grandeur of Sofia Gubaidulina, The New Yorker, Vol. 73, No. 16: 109-110.

Sofia Gubaidulina, Published by Sikorski Musikverlage, SIKORSKI, Printed editions, Hamburg, SIK KAT 9945.

Sofia Gubaidulina. A Complete Catalogue, Published by Sikorski Musikverlage, 20139 Hamburg, 23. 11. 2016.

Scores

De Profundis (for solo accordion) by Sofia Gubaidulina, Copyright: Musikverlage Hans Sikorski, Hamburg scores: 8742

Scores: Sonata Et Exspecto (for solo accordion) by Sofia Gubaidulina, Copyright: Musikverlage Hans Sikorski, Hamburg scores: 8743

Scores: In Croce (version for violoncello and bayan) by Sofia Gubaidulina, Copyright: Musikverlage Hans Sikorski, Hamburg scores: 1940 
Web Sites

https://www.biblegateway.com/passage/?search=Psalm+130 (accessed on 29. 05. 2017)

http://www.barynya.com/russianmusic/Bayan-russian-accordion.htm (accessed on 28. 05. 2017)

\section{ODNOS PREMA BOGU SOFIJE GUBAJDULINE - KOMPOZICIONE, TEHNIČKE I INTERPRETATIVNE KARAKTERISTIKE NJENE MUZIKE}

U radu su prikazane kompozicije De Profundis i Et Exspecto za solo harmoniku i In Croce za harmoniku i violončelo, jedne od najznačajnijih kompozitorki današnjice, Sofije Gubaiduline. De profundis je prvo delo Gubaiduline za solo harmoniku napisano 1978. godine. U ovoj kompoziciji ona menja uobičajen zvuk harmonike koji je susretala u ruskoj narodnoj muzici, tako da zvuk ovog instrumenta dobija potpuno novu dimenziju. Et Exspecto je kompozicija napisana 1985. godine $i$ sastoji se iz pet stavova. Kompozitorka se u ovom delu izražava putem raznih sredstava: dugmetom za meh, brzim pasažima, tremolom, statičnim i pokretljivim klasterima, akordima raznih vrsta, talasastim zvukom, vibratom, tihim koralnim zvukom i dr. In Croce je delo napisano 1979. godine za violončelo i orgulje posvećeno čelisti Vladimiru Tonki. Gubaidulina je zajedno sa Elzbet Mozer 1991. godine rearanžirala In Croce za harmoniku i violončelo.U kompoziciji na specifičan način dolazi do ukrštanja melodijskih linija koje kod slušaoca stvaraju vizuelni utisak krsta.

Ključne reči: savremena muzika, Sofia Gubaidulina, De Profundis, Et Exspecto, In Croce 